\title{
Providing for Distance Students
}

by Julie Willems, Siong Ng and Alice Ferguson

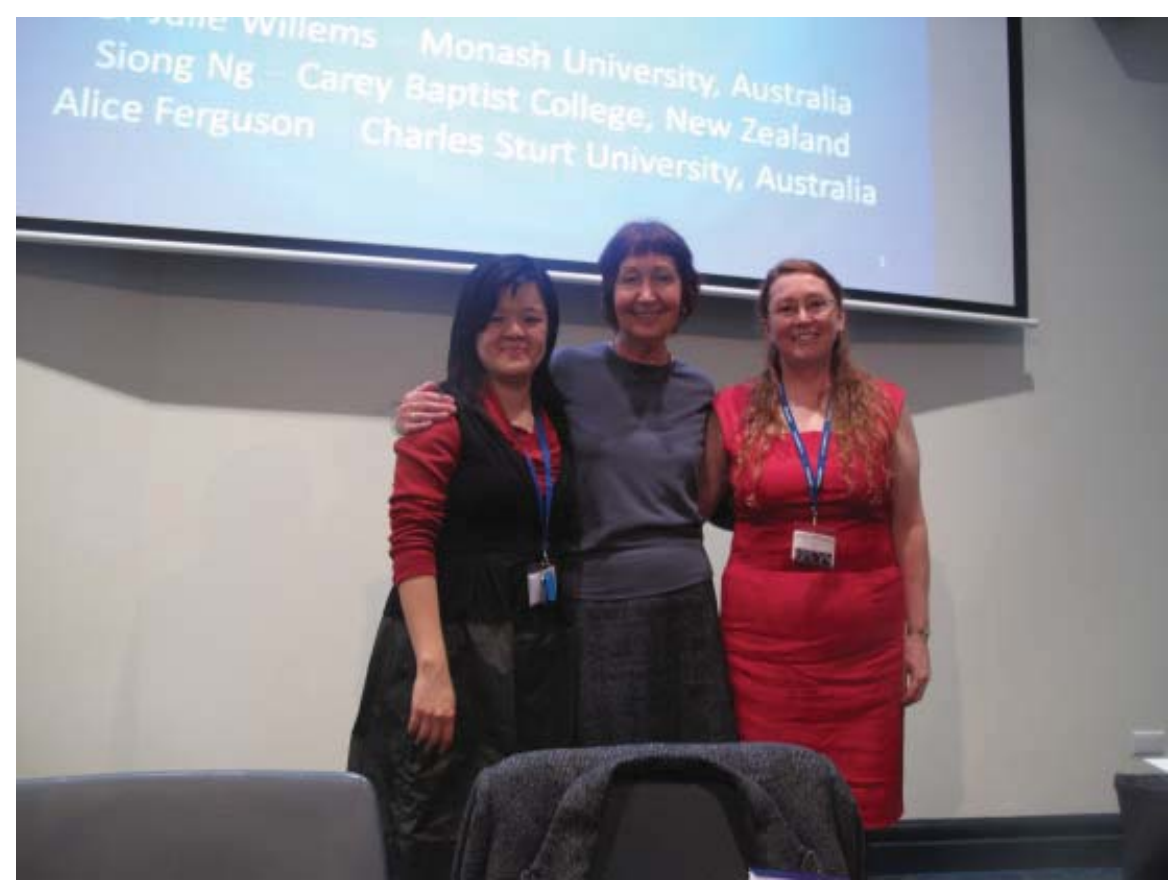

Trax4Transition - ANZTLA Conference 2012

\section{Providing for} distance students

Dr Julie Willems - Monash University, Australia Siong Ng - Carey Baptist College, New Zealand Alice Ferguson - Charles Sturt University, Australia 
Dr. Julie Willems,

Educational Developer/ E-Learning Designer, MUDRIH,

Monash University.

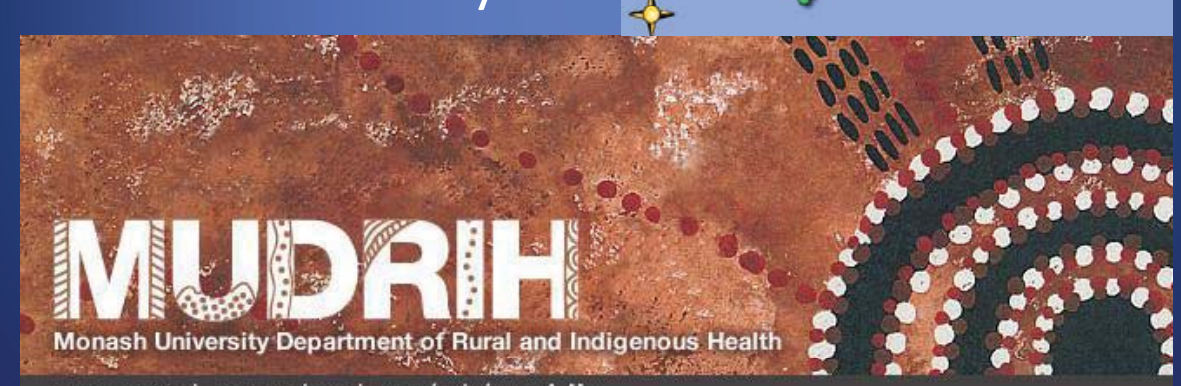

www.med.monash.edu.au/srh/mudrih

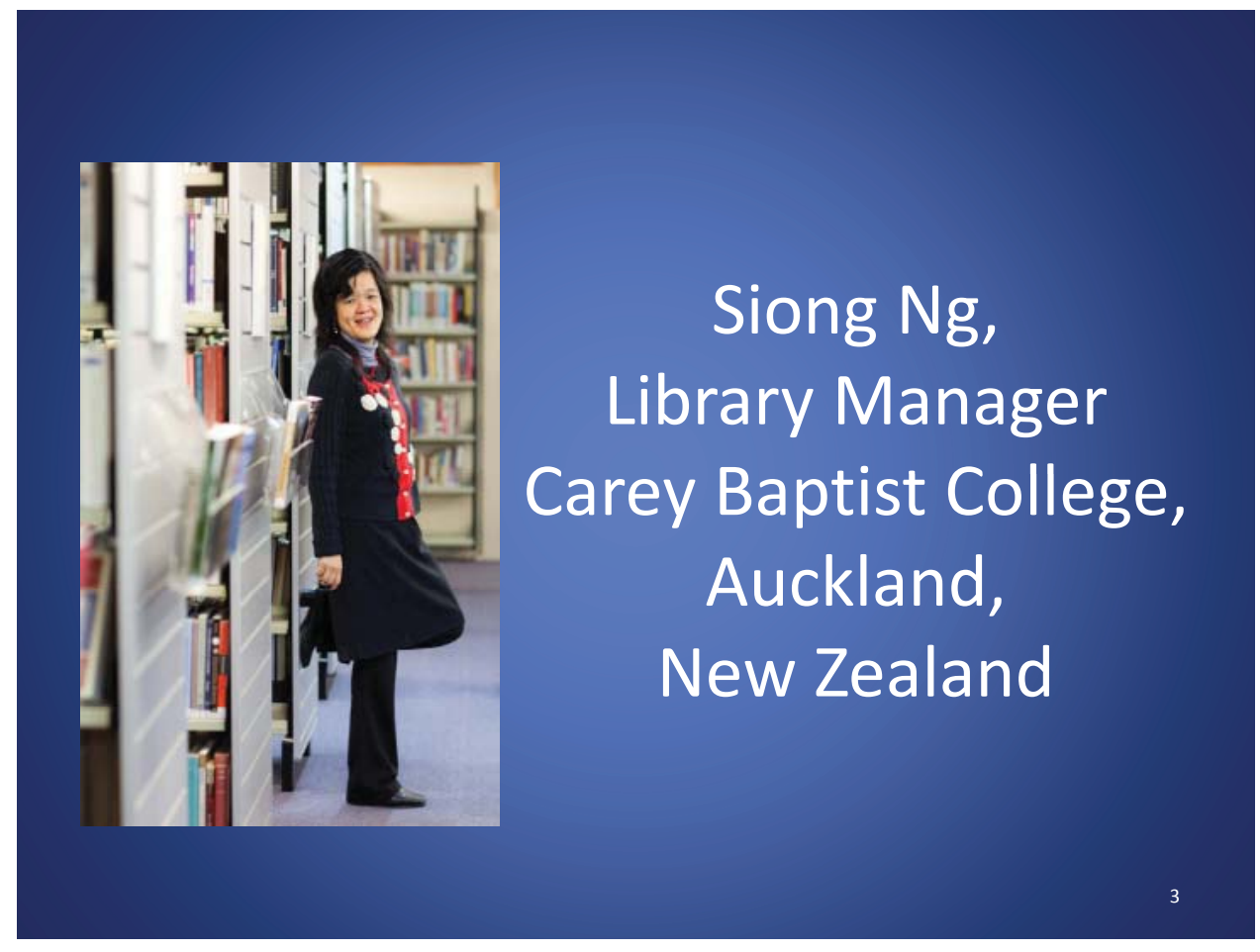




\section{Alice Ferguson Director, Client Services Division of Library Services Charles Sturt University, Australia}

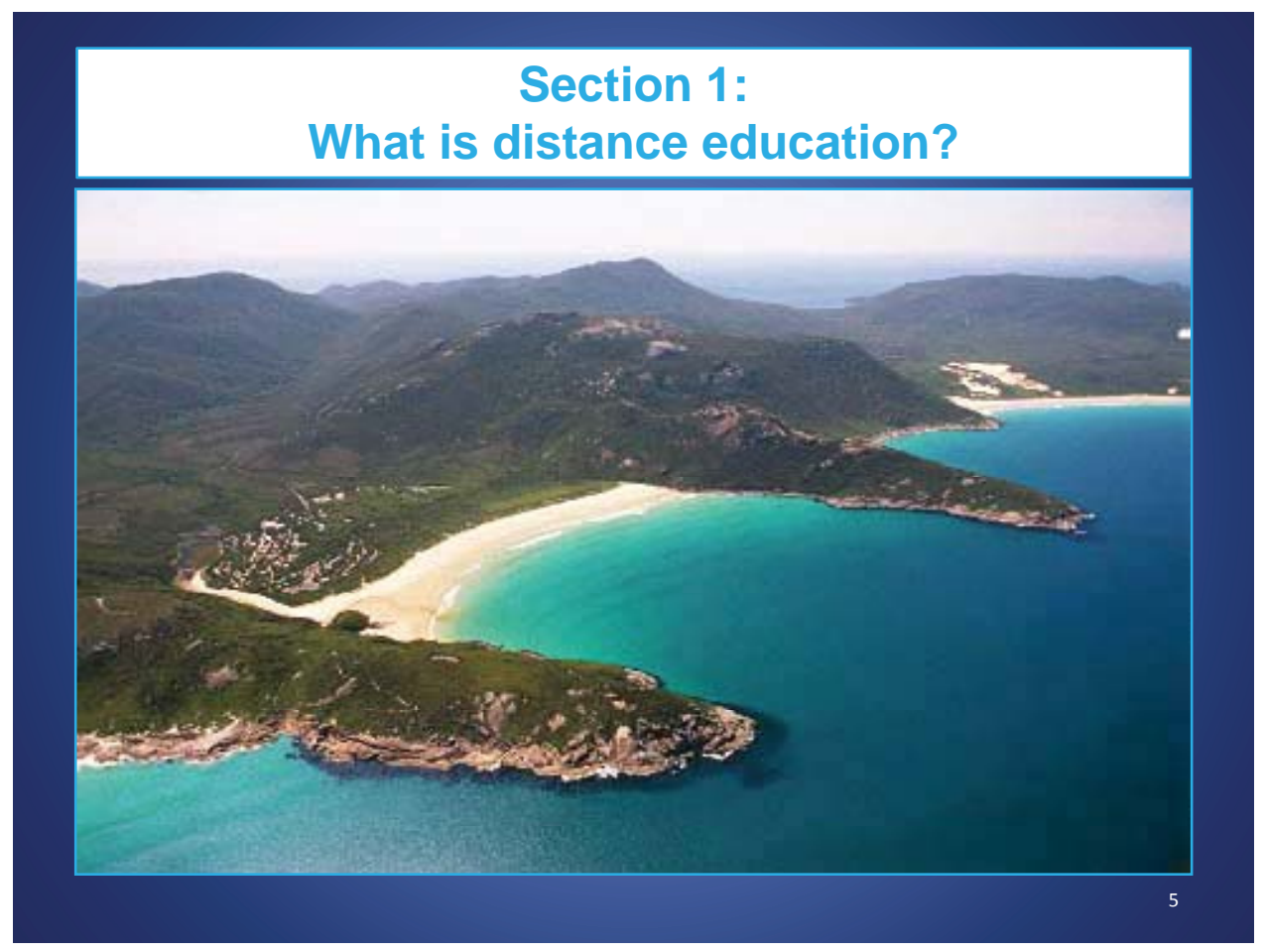




\section{Historical snapshot: Overcoming the 'tyranny of distance'}

- First DE course attributed to Sir Isaac Pitman in England in 1840.

- Qualified teacher who taught shorthand who decided to start a correspondence course for distant students.

- Sent assignments to his students by mail.

- They completed the 'homework' and sent it back to him for assessment.

- Isaac's brother, Benn Pitman, took the system to the USA.
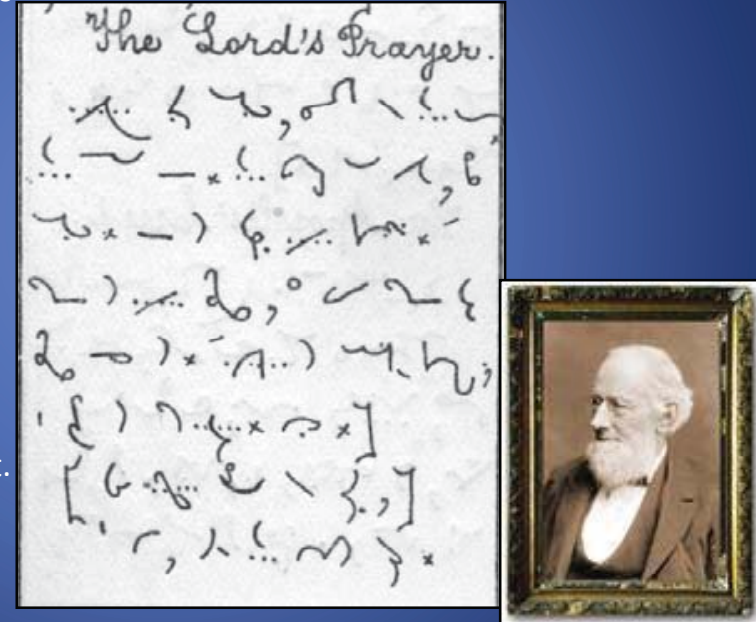

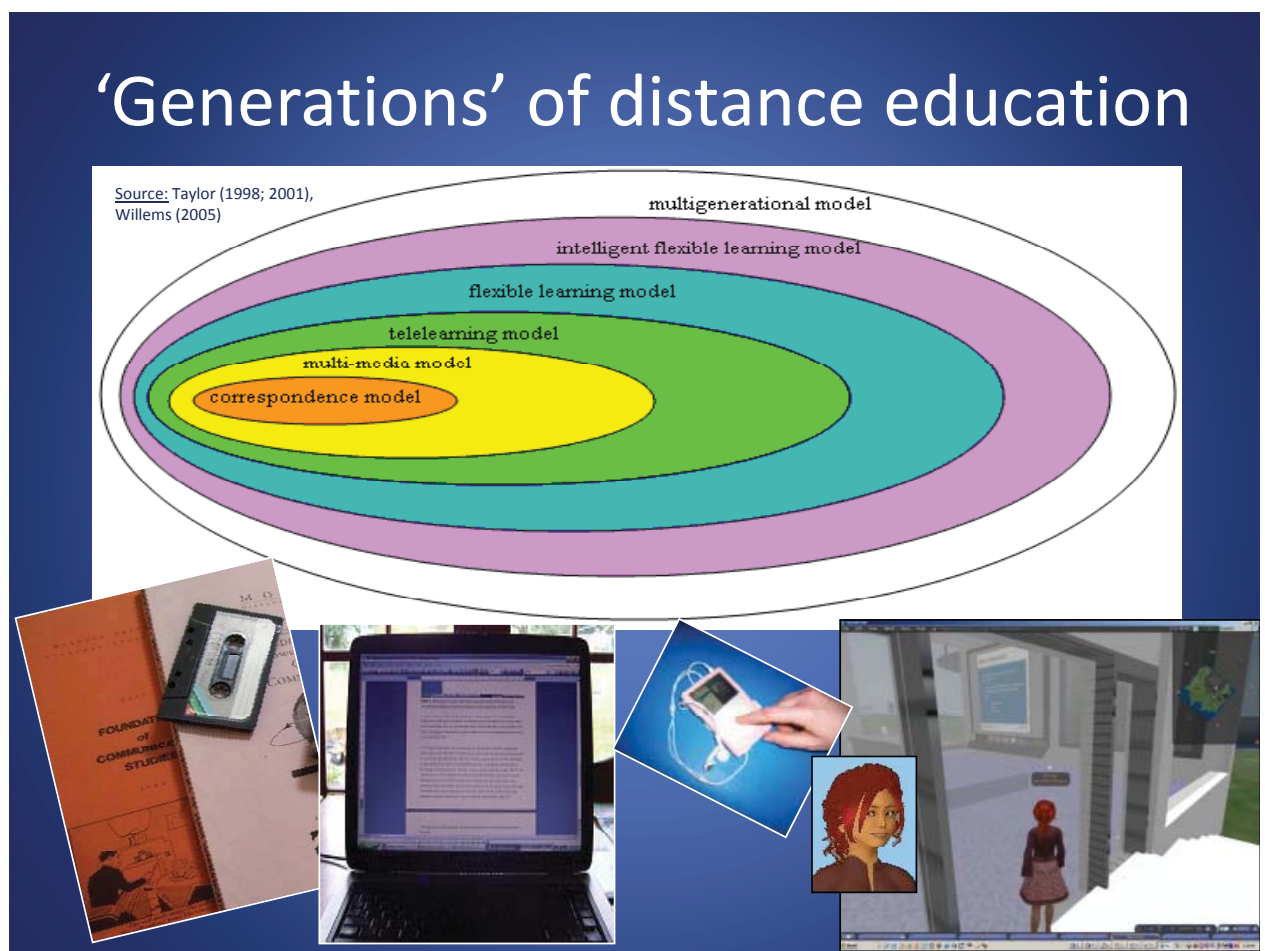




\section{Providing for distance learners}

Much to consider...

- Theory or skills;

- Individual needs;

- Variety of contexts;

- Modes of delivery;

- Learning styles;

- Accessibility issues;

- Time availability;

- Literacy;

- Digital literacy;

- Desired outcomes;

- Disabilities; etc.

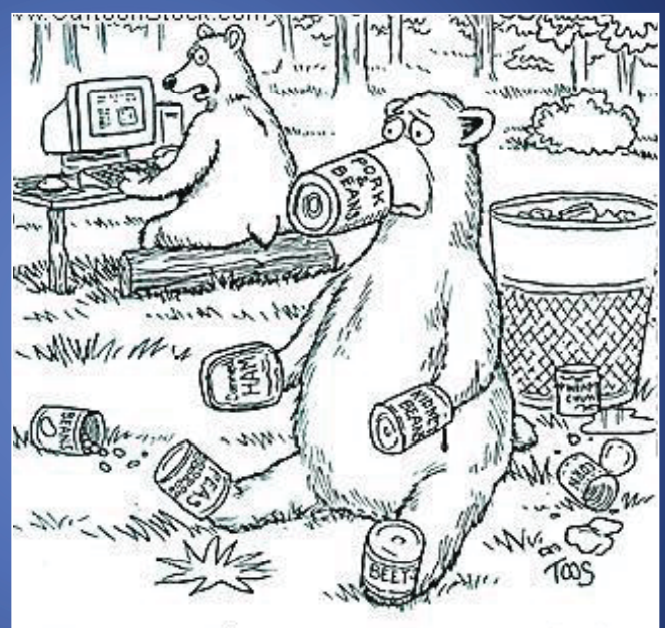

"Henry, I'm beginning to think we're on different career paths."

\section{Section 2:}

Two research projects on distance learners

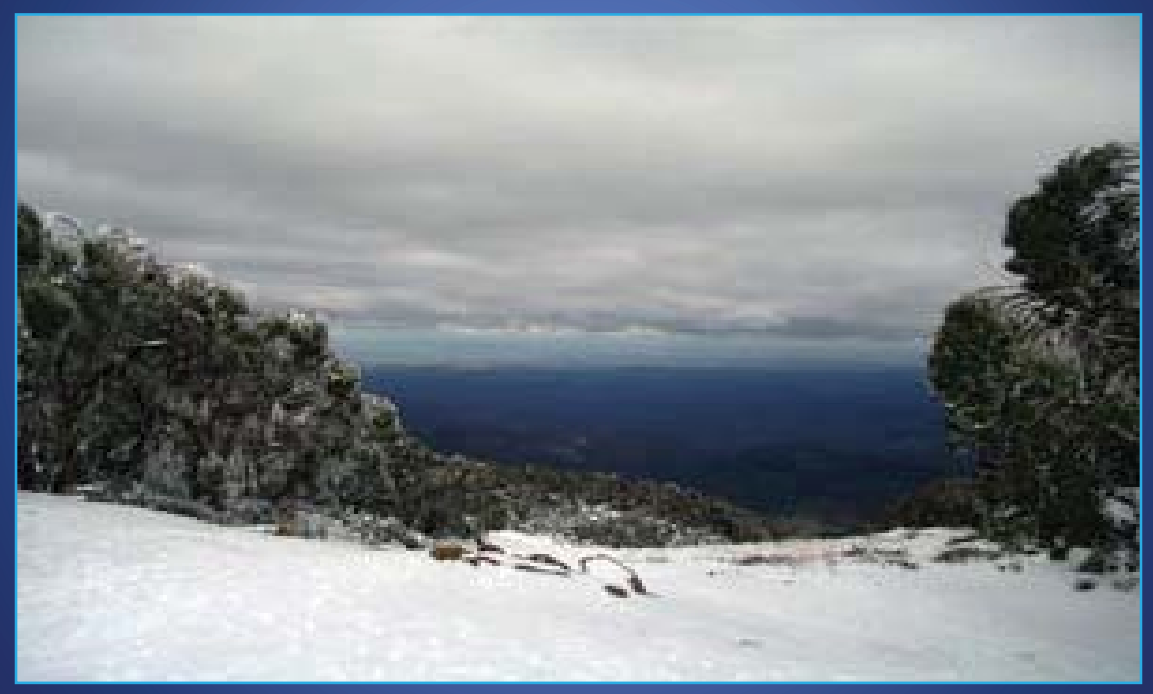




\section{Research project 1 (Siong Ng)}

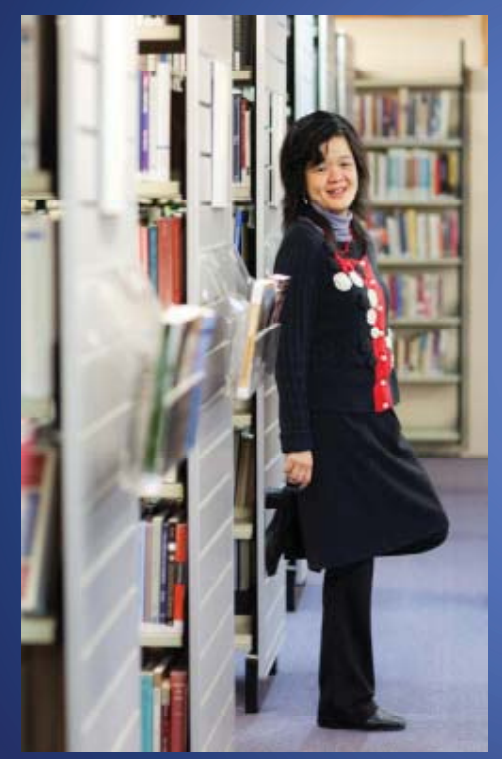

Conducted a mixed method research in 2011

Information seeking behaviour of distance students in theological libraries in New Zealand

Funded by the Szentirmay scholarship

\section{Advantages}

- Less physical space needed

- No barrier. Social status e.g. gender, age, physical ability, personality or ethnicity does not matter. Socially friendly

- It brings joy to students when the books just arrived on the door step

\section{Disadvantages}

- Generally requires more work helping them online

- No immediate feedback. Can be time consuming waiting for them to reply. Librarians need to be confident using Reference Interview skills

- Postage cost and delivery time

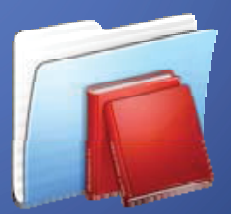


- Increase or start to build online resources

- Variation in your job

- The availability of free online resources for students e.g. Google books/Scholar is much more convenient now

- Think beyond your four walls
- You do need an IT expert to handle all those problems! Security issues

- Consistently need to evaluate services/resources

- A number of core reference books are not available in any format

- Librarians familiar with other library resources e.g. public library. Able to direct students when necessary

\section{Major findings from the study}

1) Where do undergraduate theology distance students look for information

The findings indicate that course readings,

Logos Bible Software, and

Internet search engines are the first platforms of information for distance students.

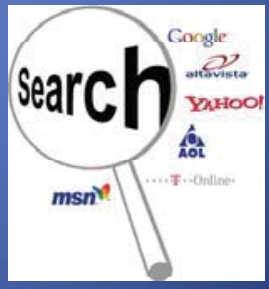


2) How do these students describe their information process?

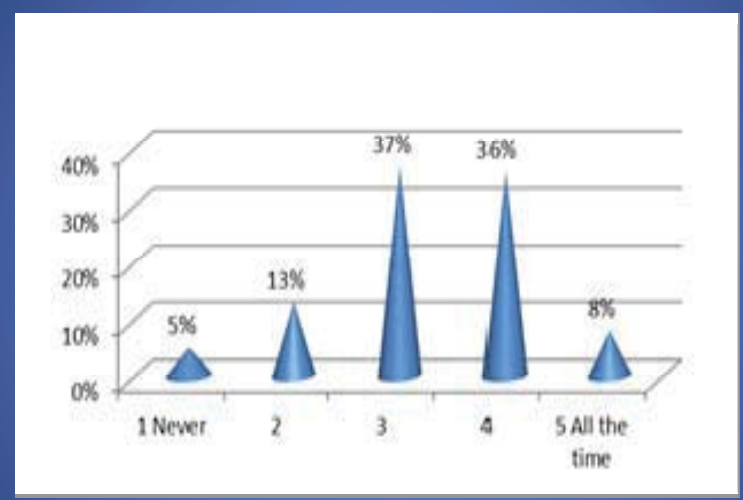

3. How do these students describe the use of electronic information resources in their information seeking?

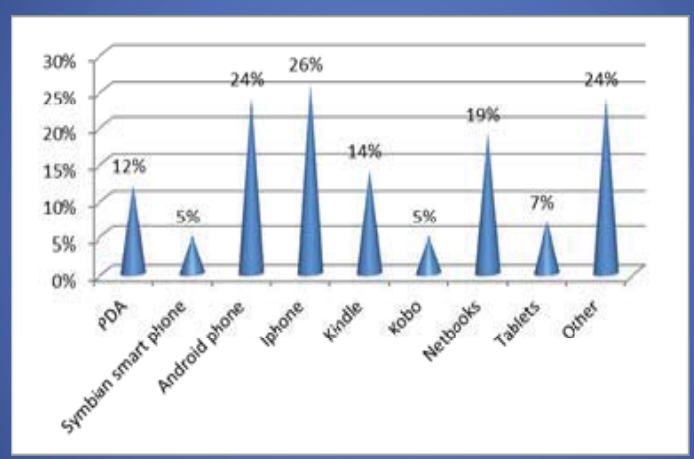


The proposed information seeking model for distance students.

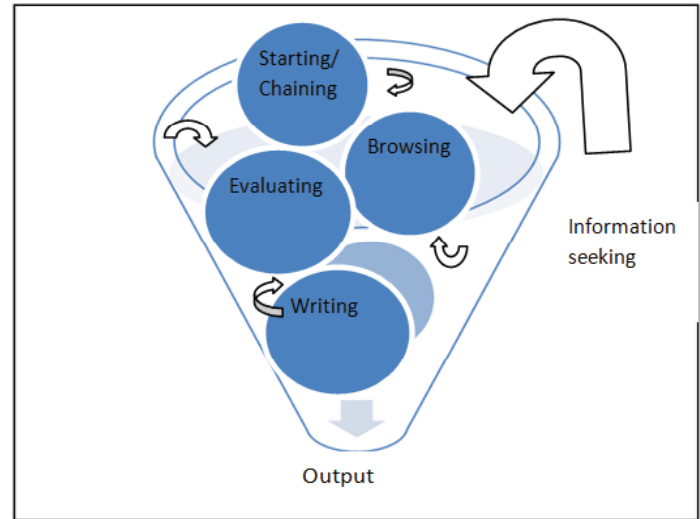

\section{Research project 2 (Julie Willems)}

$>$ Ethnographic case study research (2000 to 2004);

$>$ Study aimed to investigate the experiences of online distance learners (their perceived advantages and disadvantages to successful participation);

$>\mathrm{n}=\mathbf{3 5}$ distance learners participating in online learning environments ;

$>33$ of these respondents were a member of at least 1 equity group at time of study. $>$ Yet there were obvious 'intra-group differences' in the experiences within both the equity and non-equity cohorts. How could these be explained?

$>$ There are socio-cultural sub-groups not only within equity groups but across the entire student population (eg. literacy skills; ICT access; 'first in the family'; etc.);

$>$ Equity sub-groups affect all student groups, including those identified as members of equity ('under-represented' groups) as well as those not traditionally examined for in terms of disadvantage

\begin{tabular}{|c|c|c|c|c|c|c|c|c|}
\hline Participant & $\begin{array}{c}\text { Equity } \\
\text { group(s) }\end{array}$ & \begin{tabular}{|c} 
Equity sub- \\
group(s)
\end{tabular} & Participant & $\begin{array}{l}\text { Equity } \\
\text { group(s) }\end{array}$ & \begin{tabular}{|c} 
Equity sub- \\
group(s)
\end{tabular} & Participant & $\begin{array}{c}\text { Equity } \\
\text { group(s) }\end{array}$ & \begin{tabular}{|c} 
Equity sub- \\
group(s)
\end{tabular} \\
\hline 1 & 2 & 4 & 13 & 3 & 5 & 25 & 2 & 3 \\
\hline 2 & 2 & 2 & 14 & 0 & 0 & 26 & 2 & 0 \\
\hline 3 & 1 & 0 & 15 & 2 & 2 & 27 & 3 & 4 \\
\hline 4 & 1 & 2 & 16 & 3 & 2 & 28 & 3 & 6 \\
\hline 5 & 2 & 5 & 17 & 1 & 1 & 29 & 1 & 1 \\
\hline 6 & 4 & 4 & 18 & 3 & 5 & 30 & 1 & 0 \\
\hline 7 & 2 & 2 & 19 & 3 & 7 & 31 & 2 & 1 \\
\hline 8 & 2 & 3 & 20 & 2 & 3 & 32 & 4 & 6 \\
\hline 9 & 4 & 4 & 21 & 0 & 1 & 33 & 2 & 3 \\
\hline 10 & 2 & 4 & 22 & 2 & 4 & 34 & 1 & 1 \\
\hline 11 & 2 & 3 & 23 & 2 & 2 & 35 & 4 & 6 \\
\hline 12 & 3 & 7 & 24 & 2 & 0 & & & \\
\hline
\end{tabular}




\section{Research findings = Social gradient of educational disadvantage}

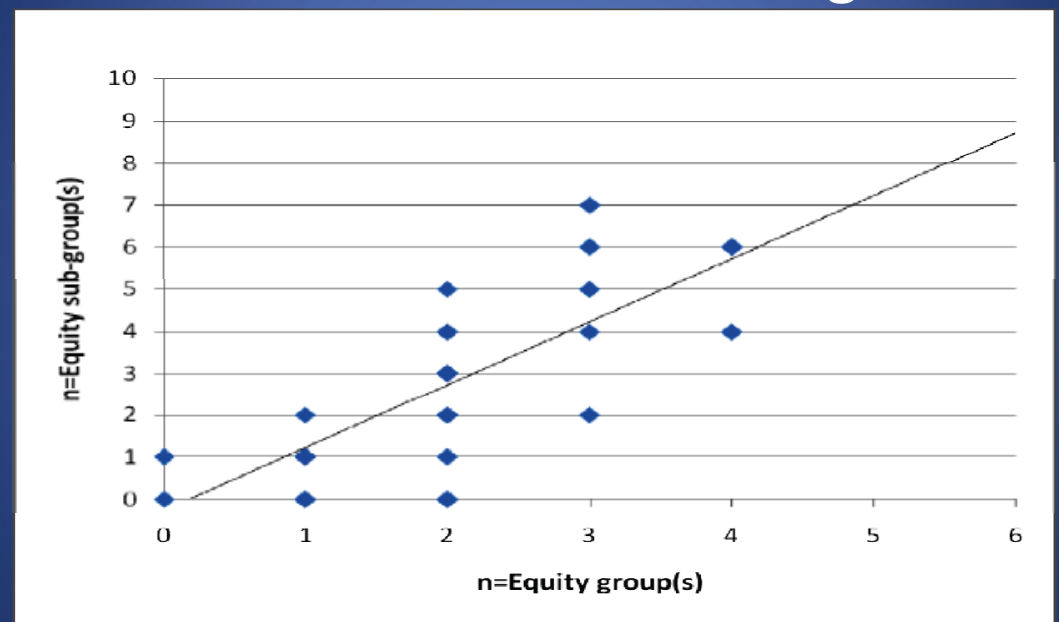

(Source: Willems, 2010)

The student population is diverse. Considerations need to be made in the provision of distance education to account for educational disadvantage.

Section 3: Providing for distance learners

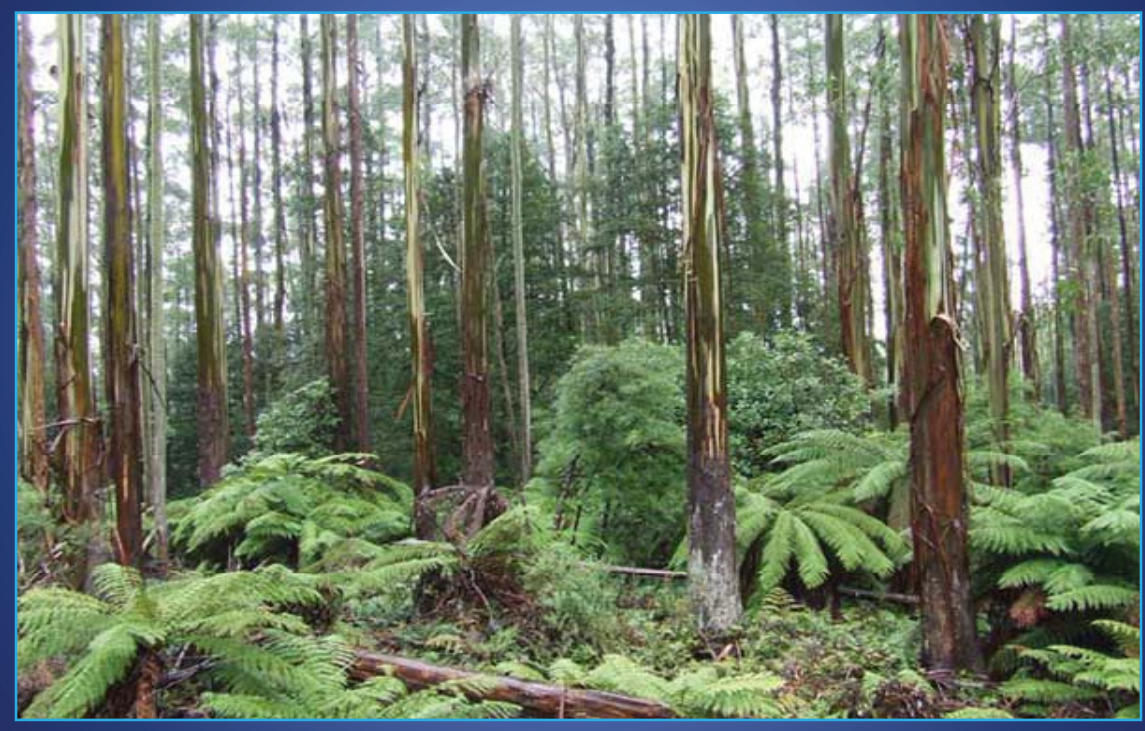




\section{CSU is the largest DE provider in Australia}

- 37,000 students

- Two thirds study by DE

- Multi-campus University

- Online and flexible delivery of courses
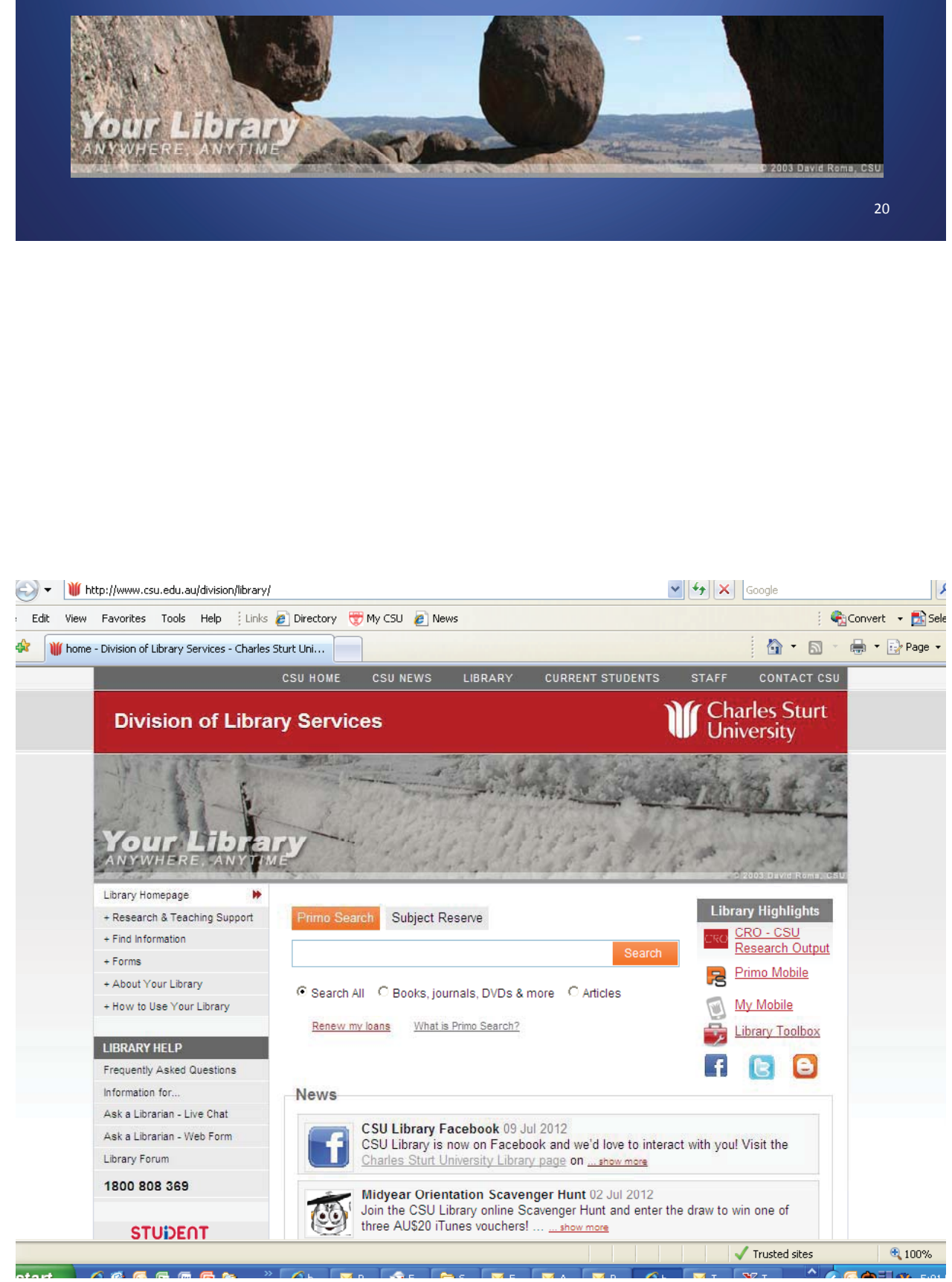


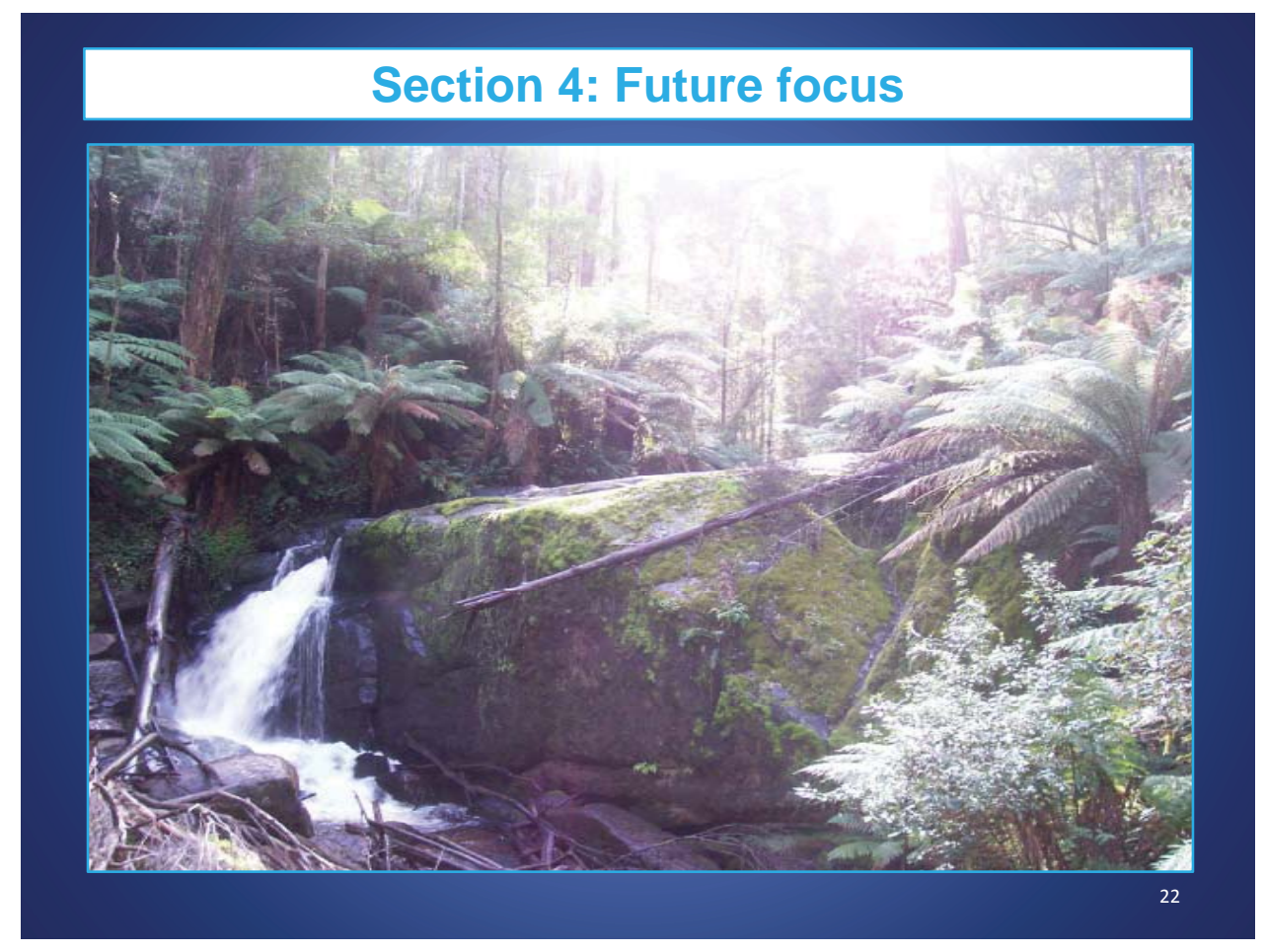

\section{Invitation:}

The Open and Distance Learning Association of Australia (ODLAA) invites you to participate in the international DE Summit:

2013 Distance Education Summit

4-7 February 2013, Novotel, Manly, Australia.

Themes:

\begin{tabular}{l|l}
$\begin{array}{l}\text { - Social, mobile, emergent, } \\
\text { informal learning }\end{array}$ & • Curriculum and teaching \\
\hline - Analytics & - Teacher roles in changing environments \\
\hline - Equity and access & $\begin{array}{l}\text { - Student-driven learning / student-developed } \\
\text { content }\end{array}$ \\
\hline $\begin{array}{l}\text { - Open educational } \\
\text { resources }\end{array}$ & - Managing and leading open and \\
\hline
\end{tabular}

SPIGs: include Librarians 
Thank you; Alknowledgments; and Questions?

E-Mail Addresses

Julie Willems:

Julie.Willems@monash.edu

Siongु Ags:

siong.ng@carey.ac.nz

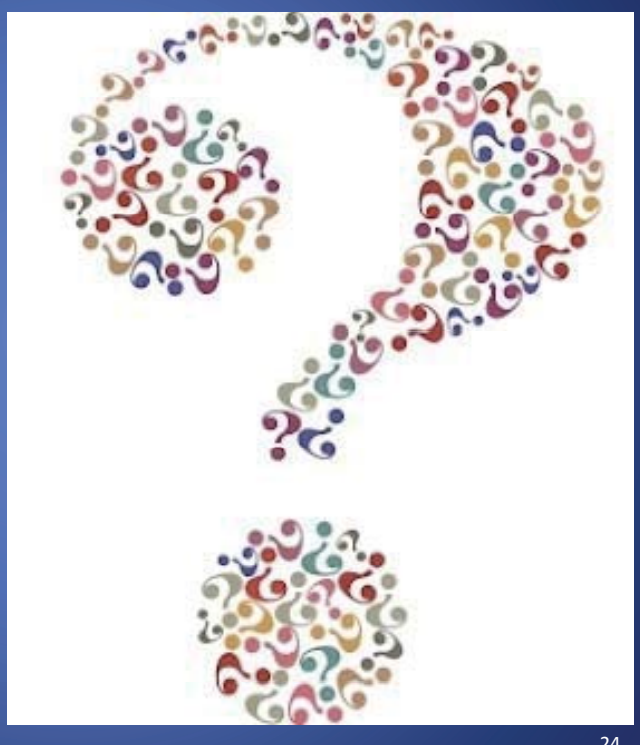

Alice Fergुuson:

aferguson@csu.edu.au 